\title{
PENGEMBANGAN ASESMEN PROYEK DALAM PEMBELAJARAN IPA DI SEKOLAH DASAR
}

\author{
I Wayan Widiana \\ Jurusan Pendidikan Guru Sekolah Dasar, \\ Universitas Pendidikan Ganesha Singaraja, Indonesia \\ Email : wayan_widiana@yahoo.co.id
}

\begin{abstract}
Abstrak
Tujuan penelitian ini adalah (1) mengetahui kualitas hasil pengembangan asesmen proyek dalam pembelajaran IPA, (2) mengetahui efektivitas asesmen proyek dalam pembelajaran IPA. Model pengembangan yang digunakan dalam penelitian ini adalah model ADDIE. Model ADDIE terdiri atas lima tahapan yaitu analisis, desain, pengembangan, implementasi, dan evaluasi. Kelima tahapan model pengembangan ini, dijadikan acuan dalam memproduksi dan memvalidasi asesmen proyek yang dikembangkan. Validasi asesmen proyek dilakukan oleh satu ahli isi mata pelajaran, satu ahli desain pembelajaran, satu ahli asesmen Pembelajaran dan 20 siswa untuk uji coba lapangan. Efektivitas asesmen proyek dilakukan oleh 29 siswa menggunakan desain penelitian pretest dan posttest. Data dikumpulkan dengan metode kuisioner dan tes. Instrumen tes yang digunakan berupa tes objektif. Dalam analisis data, digunakan analisis deskriptif kualitatif, kuantitatif dan statistik inferensial/induktif uji-t. Hasil penelitian ini adalah 1) kualitas hasil pengembangan asesmen menurut review ahli dan siswa yaitu: a) memiliki validasi persentase $96 \%$; b) memiliki persentase validasi $92 \%$; c) ahli asesmen pembelajaran $94 \%$ yang semuanya tiga ahli pada kategori sangat baik serta d) uji coba lapangan diperoleh persentase valid $91,7 \%$ yang berada pada kategori sangat baik; 2 ) Efektivitas hasil pengembangan asesmen menunjukkan signifikansi yang diperoleh adalah thitung $=13,693>$ tabel $=2,000$. Ini berarti terdapat perbedaan yang signifikan pada hasil belajar siswa sebelum dan sesudah menggunakan asesmen proyek.
\end{abstract}

Kata kunci: Asesmen Proyek, Pembelajaran IPA.

\begin{abstract}
The purpose of this study is (1) determine the quality of assessment Proyek development in science learning, (2) determine the effectiveness of the project assessment in science learning. The development model used in this study is a model ADDIE. ADDIE Model consists of five stages: analysis, design, development, implementation and evaluation. The fifth stage of this development model, used as a reference in producing and validating project assessment developed. Validation project assessment carried out by the experts of the course content, the instructional design experts, an expert assessment of students' learning and 29 field trials. Effectiveness project assessment conducted by 29 student research design of pretest and posttest. Data were collected by questionnaire method tests. With the achievement test in the use of objective tests. Analysis of data using qualitative descriptive analysis, quantitative and inferential / inductive t-test. The results of this study were; 1 ) the quality of the development of expert review and assessment by students, namely: a) the expert field of study $96 \%$; b) $92 \%$ of instructional design experts; c) expert assessment of learning $94 \%$ of which were three experts on the very good category and d) $91.7 \%$ field trials that are in the very good category; 2) Effectiveness assessment development results obtained indicate significance is t $=23.582>$ table $=2.000$. This means there is a significant difference in student learning outcomes before and after using the project assessment.
\end{abstract}

Keywords: Project Assessment, Learning Science. 


\section{PENDAHULUAN}

Pendidikan nasional bertujuan mengembangkan kemampuan dan membentuk watak serta peradaban bangsa yang bermatabat dalam rangka mencerdaskan kehidupan bangsa (Hasbullah, 2009). Untuk mencapai tujuan pendidikan nasional, berbagai upaya dilakukan untuk mecapai tujuan tersebut, mulai dari pelatihan untuk meningkatkan kualitis guru, perbaikan sarana dan prasarana pendidikan dan penyempurnaan kurikulum secara periodik.

Perubahan dan perkembangan Kurikulum terus dilakukan, hingga akhirnya dari Kurikulum KBK yang disosialisasikan pertengahan tahun 2001 oleh Departemen Pendidikan Nasional, kini telah disempurnakan menjadi kurikulum KTSP yang dilaksanakan mulai tahun 2006 (dalam Muslich, 2009:11). Dengan KTSP diharapkan celah kelemahan dan kekurangan yang terdapat dalam KBK bisa ditanggulangi, baik pada perencanaan pembelajaran, pelaksanaan, dan evaluasi.

Nitko dan Brookhat (dalam Rasyid 2007:2) mendefinisikan evaluasi sebagai suatu proses penetapan nilai yang berkaitan dengan kinerja dan hasil karya siswa. Dalam evaluasi terdapat sebuah penilaian dimana penilaian merupakan salah satu komponen pokok dalam proses pembelajaran. Teknik penilaian dalam pembelajaran terus berkembang, dengam harapan dapat meningkatkan kualitas pembelajaran. Teknik penilaian yang digunakan harus disesuaikan dengan karakteristik indikator, standar kompetensi dan kompetensi dasar. Tidak menutup kemungkinan bahwa satu indikator dapat diukur dengan beberapa teknik penilaian, hal ini karena memuat domain kognitif, psikomotor, dan afektif. Dari ke tiga ranah yang dimaksud akan dilaporkan pada peserta didik dan orang tua dalam bentuk rapor.

Tujuan penilaian (asesmen) adalah untuk mengetahui tingkat ketercapaian tujuan pembelajaran dan melihat keefektifan proses belajar mengajar (dalam Rasyid, 2007:26). Hal ini penting, mengingat tidak jarang ada sebagian guru yang melakukan penilaian hanya sekedar melakukan kewajiban. Karena itu terkadang ada siswa yang karena rajin diberi nilai lebih sedangkan siswa yang malas diberi nilai yang rendah. Perlu diingat bahwa seperti yang didefinisikan Weeden, Winter \& Broadfoot (dalam Rasyid 2007:7) penilaian merupakan pengumpulan informasi tentang kinerja siswa, untuk digunakan sebagai dasar dalam membuat keputusan, semua penilaian harus diacukan pada tujuan pembelajaran yang sudah ditetapkan. Jenis dan model penilaian yang digunakan bisa beragam tergantung pada jenis kompetensi, indikator hasil belajar yang ingin dicapai, materi pembelajaran dan tujuan penilaian itu sendiri.

Jadi penilaian itu untuk melihat keefektifan proses belajar mengajar dan untuk menafsirkan data hasil pengukuran pembelajaran. Penilaian yang diwujudkan di sekolah memiliki tujuan dan karakteristik masing-masing, seperti halnya penilaian dalam mata pelajaran IPA. IPA pada hakekatnya merupakan suatu produk, proses dan aplikasi. Sebagai produk IPA merupakan sekumpulan pengetahuan dan sekumpulan konsep dan bagan konsep. Sebagai suatu proses, IPA merupakan proses yang dipergunakan untuk mempelajari objek studi, menemukan dan membangun produk-produk sains, dan sebagai aplikasi, teori-teori IPA akan melahirkan teknologi yang dapat memberi kemudahan bagi kehidupan (dalam Trianto 2007:137), berdasarkan hal tersebut maka penilaian dalam IPA perlu menggunakan penilaian yang tidak hanya mengacu pada ranah kognitif saja tetapi perlu penilaian yang dapat mengukur keterampilan siswa. Sehubungan dengan hal tersebut guru harus memberikan tugas proyek untuk siswa.

Tugas proyek adalah tugas yang harus diselesaikan siswa dalam periode waktu tertentu (Wahyuni dan Ibrahim, 2012). Tugas tersebut berupa suatu ivestigasi sejak dari pengumpulan, pengorganisasian, pengevaluasi hingga menyajikan data. Dalam tugas proyek siswa mendapat kesempatan ketrampilannnya. 
Marhaeni (2007) juga menyatakan bahwa asesmen proyek adalah investigasi mendalam mengenai suatu topik nyata, dimana siswa mendapat kesempatan mengaplikasikan keterampilannya. Pelaksanaan proyek dapat dianalogikan dengan sebuah cerita, yaitu memiliki fase awal, pertengahan, dan akhir proyek. Hal ini berarti bahwa asesmen proyek dapat digunakan untuk mengetahui pemahaman, kemampuan mengaplikasikan, kemampuan penyelidikan dan kemampuan menginformasikan dari siswa pada mata pelajaran tertentu secara jelas. Salah satu dari asesmen yang bermakna, tentunya implementasi Asesmen proyek harus sesuai dengan karakteristik pembelajaran yang dilakukan.

Karena guru perlu menggunakan penilaian proyek untuk menilai pembelajaran dalam pembelajaran IPA, seperti yang didefinisikan Uno (2012), penilaian proyek merupakan kegiatan penilaian terhadap suatu tugas yang harus diselesaikan dalam waktu tertentu sejak dari perencanaan, pengumpulan data, pengorganisasian, pengolahan dan penyajian data.

Pada tahap perencanaan, siswa merumuskan pokok permasalah yang nantinya akan diteliti dan diamati. Selain itu, pada tahap perencanaan ini siswa juga membuat jadwal pelaksanaan proyek, tempat/lokasi, alat dan bahan, dan lainnya sesuai dengan guru pembingbing. Setelah pokok masalah dirumuskan, langkah selanjutnya adalah pelaksanaan proyek. Pada tahap ini siswa dapat terjun ke lapangan untuk mengamati dan menghimpun data. Pengumpulan data akan tergantung dengan masalah pokok dan proyek. Apakah proyek difokuskan pada proses atau produk. Langkah selanjutnya adalah pengorganisasian, yaitu data yang telah dihimpun dari lapangan kemudian dikelompokkan sesuai dengan pokok-pokok masalah maka data tersebut di interpretasikan atau dianalisis, tahapan ini dinamakan pengolahan data dan setelah data dianalisis sampai pada pengambilan kesimpulan selanjutnya adalah menyusun laporan atau penyajian data.

Berdasarkan hasil observasi dan wawancara pada tangga 30 Oktober 2015 yang dilakukan dengan guru IPA di kelas $\mathrm{V}$ SD Negeri 1 Sangsit diperoleh hasil bahwa guru belum pernah melakukan penilaian proyek (asesmen proyek) dalam mengevaluasi pembelajaran IPA di kelas $\mathrm{V}$, guru hanya menggunakan tes sebagai cara mengevaluasi kemampuan siswa, sehingga guru mengalami kesulitan untuk mengetahui sejauh mana kemampuan siswa mengaplikasikan materi yang sudah dipelajari, selain itu hasil belajar siswa dalam pelajaran IPA sangat rendah karena siswa didalam kelas kurang begitu aktif, siswa dituntut untuk mengafalkan teori dan jarang diberikan tugas setiap akhir pembelajaran sehingga kemampuan siswa dalam memahami dan mengingat materi dalam jangka waktu panjang masih rendah.

Pembelajaran merupakan suatu proses penyampaian pengetahuan, yang dilaksanakan dengan menuangkan pengetahuan kepada siswa (Khusniati, 2012). Morrison dan Estes (2007) menyatakan bahwa aplikasi skenario dunia nyata merupakan strategi yang efektif untuk mengajarkan IPA sebagai proses. Dalam pembelajaran IPA perlu memiliki strategi mengajar yang lebih inovatif agar bidang studi yang dibelajarkan mampu diserap dengan baik. Mata pelajaran IPA adalah salah satu mata pelajaran dasar yang wajib dibelajarkan dengan mengikutsertakan benda-benda lain yang mendukung pembelajaran tersebut (Listyawati, 2013). Proses pembelajaran IPA memadukan berbagai konsep fisika, kimia, biologi, dan bumi antariksa lebih berpotensi untuk mengembangkan pengalaman dan kompetensi siswa memahami alam sekitar (Listiawati, 2012).

Pembelajaran IPA di sekolah dasar memegang peranan penting dalam pembelajaran IPA di jenjang-jenjang berikutnya sebab pengetahuan awal siswa sangat berpengaruh pada minat dan kecendrungan siswa untuk belajar IPA. Dengan kata lain jika minat siswa pada saat pembelajaran IPA di SD sudah rendah kemungkinan untuk jenjang selanjutnya hal yang sama akan terjadi. Dalam kurikulum tingkat satuan pendidikan dijelaskan tentang pentingnya pembelajaran IPA ini (Depdiknas, 2006) salah satunya adalah mengembangkan rasa ingin tahu, sikap 
positif dan kesadaran tentang adanya hubungan yang saling mempengaruhi antara IPA, lingkungan, teknologi dan masyarakat melalui pendekatan scientific inquiry.

Sejalan dengan hal itu NRC (1996) menyebutkan bahwa ada enam standar seorang guru dapat melaksanakan pembelajaran IPA sebagai berikut: satu Dapat merencanakan pembelajaran IPA yang berbasis Inkuiri; dua Melaksanakan pembelajaran untuk mengarahkan dan menfasilitasi siswa belajar; tiga Penilaian disesuaikan dengan kegiatan guru mengajar dan berkesusaian dengan pembelajaran siswa; empat Mengembangkan pembelajaran dari lingkungan dimana siswa belajar; lima. Menciptakan masyarakat pembelajar sains dan enam Merencanakan dan mengembangkan pembelajaran dari program IPA sekolah Selama ini menurut Rustaman dalam Depdiknas (2007) pembelajaran IPA disekolah terbatas hanya penguasaan konsep belaka. Artinya pembelajaran IPA menyimpang dari hakikat IPA yang sebenarnya. Kenyataan ini tidak lazim, karena pembelajaran IPA tidak mencapai tujuan dasarnya hanya sebatas pemindahan pengetahuan saja tidak membangun sikap ilmiah yang benar. Ditambahkannya lagi bahwa kenyataan ini menyebabkan siswasiswa Indonesia tersebut diduga baru mampu mengingat pengetahuan ilmiah berdasarkan fakta sederhana

Menurut Kemendiknas (dalam Purnamasara, 2015) pembelajaran IPA berbasis pendidikan karakter diharapkan terbentuk 30 nilai karakter siswa. peduli kesehatan, nilai intelektual, religius, empati, mandiri, disiplin, toleransi, hati-hati, bersahabat/ berkomunikasi, peduli sosial, tanggung jawab, peduli lingkungan, nilai susila, kerja keras, rasa ingin tahu, senang membaca, estetika, nilai ekonomi, kreatif, teliti, skeptis, menghargai prestasi, pantang menyerah, terbuka, jujur, cinta damai, objektif, hemat, percaya diri, dan cinta tanah air, tetapi pada kenyataannya pendidikan karakter yang terbangun belum sesuai. Pembelajaran IPA tidak lepas dari media dan bahan ajar yang digunakan. Akan tetapi, media dan bahan ajar yang beredar di lapangan belum sesuai dengan harapan pemerintah kaitannya dengan materi IPA terpadu (Puspitoroni, 2014) IPA harus diajarkan dengan pembelajaran yang memungkinkan siswa mengembangkan kemampuan yang dimilikinya dan dapat membangun sendiri konsepnya. Dasar dari pembelajaran tersebut adalah pembelajaran konstruktivisme (Rizal, 2014)

Pelajaran IPA merupakan salah satu mata pelajaran yang penting ditanamkan pada anak didik karena melalui pembelajaran IPA, siswa mampu bersikap ilmiah dalam memecahkan masalahmasalah yang dihadapi (Rusnadi, 2013). Pembelajaran IPA diharapkan dapat menjadi wahana bagi siswa untuk mempelajari diri sendiri dan alam sekitar, serta prospek pengembangan lebih lanjut dalam menerapkannya di dalam kehidupan sehari-hari (susiani, 2013) Menurut (Trisnani, 2015) pelajaran IPA memiliki peranan penting dalam perkembangan manusia, baik dalam hal perkembangan teknologi yang dipakai untuk menunjang kehidupanya maupun dalam hal penerapan konsep.

Berdasarkan alasan di atas maka diputuskan untuk mengembangkan asesmen proyek dalam pembelajaran IPA di kelas V SD Negeri 1 Sangsit. Dengan adanya penilaian proyek, guru dapat mengukur keterampilan siswa dalam menyelidiki secara umum, pemahaman dan pengetahuan dalam pembelajaran IPA, serta kemampuan mengaplikasi pengetahuan dan keterampilan siswa dalam pebelajaran.

\section{METODE}

Model pengembangan asesmen proyek dalam pembelajaran IPA di SD Negeri 1 Sangsit menggunakan model ADDIE (Tegeh dan Kirna, 2010). Pemilihan model pengembangan ini didasari atas pertimbangan bahwa model pengembangan ADDIE merupakan model desain pembelajaran yang berlandaskan pada pendekatan sistem yang efektif dan efisien serta prosesnya yang bersifat interaktif yakni hasil evaluasi setiap fase dapat membawa pengembangan pembelajaran ke fase selanjutnya. Hasil akhir dari suatu fase merupakan produk awal bagi fase berikutnya. Model ini terdiri atas 5 fase yaitu: 
Analyze (Analisis); Design (Desain); Development (Pengembangan); Implementation (Implementasi) dan Evaluation (Evaluasi) (Brog \& Gall dalam Tegeh \& Kirna, 2010).

Pada tahap analisis, terdiri dari lima jenis kegiatan yang dilakukan, yaitu analisis awal akhir yaitu analisis yang dilakukan untuk memunculkan dan menetapkan masalah dasar yang dihadapi guru dalam pembelajran IPA di SD Negeri 1 Sangsit melalui wawancara; analisis siswa yaitu analisis yang dilakukan untuk melihat dan menelaah karakteristik siswa berdasarkan kebutuhan dan perkembangannya sebagai titik acuan untuk membuat rancangan pengembangan Asesmen Proyek dalam pembelajaran IPA.

Analaisis ini menjamin ketercakupan secara menyeluruh aspek keterampilan yang dikembangkan; analisis tugas yaitu analisis yang dilakukan untuk mendeskrikan tugas yang akan dikembangkan dalam pembuatan Asesmen Proyek, ini meliputi perkembangan tugas siswa terhadap pembelajaran; analisis konsep yaitu analisis yang dilakukan untuk mengidentifikasi konsep-konsep berupa aspek-aspek yang relevan untuk mengembangkan instrument Asesmen Proyek dalam pembelajaran IPA dan analisis tujuan pembelajaran yaitu untuk mengubah analisis tugas dan analisis konsep menjadi tujuan pembelajaran sesuai dengan indikator pembelajaran yang hendak dicapai dalam suatu pembelajaran Tujuan dari tahap design yaitu untuk menyiapkan rancangan instrumen Asesmen proyek dalam pembelajaran IPA. Tahap ini terdiri atas empat langkah yaitu: penyusunan kisikisi instrument; penentuan skala instrument; pembuatan kriteria penilaian atau rubrik, dan perancangan asesmen proyek. tahap ini adalah untuk menghasilkan instrumen asesmen proyek yang sudah direvisi berdasarkan masukan dari ahli dan uji lapangan. Tahap ini terdiri dari beberapa tahapan yaitu: validasi pakar dan validasi oleh guru. Langkah penerapan asesmen proyek dalam pembelajaran IPA dirancang serta dikemas sedemikian rupa sesuai dengan peran dan fungsinya agar dapat diterapkan.

Dalam penerapan produk hal yang
harus dilakukan sebagai berikut: menyiapkan alat-alat yang diperlukan selama proses pembelajaran seperti materi pembelajaran, tugas yang akan diberikan serta instrumen penilaian yang akan digunakan yaitu asesmen proyek dan berkoordinasi dengan guru yang mengajar sehingga terjadi kolaborasi yang baik antara pengembang dan guru.

Implementasi program berjalan sesuai dengan yang telah direncanakan, dan secara lebih spesifik akan dijabarkan pada uji coba produk. Tahap evaluasi dilakukan untuk mengevaluasi proses pengembangan produk dari analisis hingga produk diimplementasikan. Adapun tahapan yang dilakukan sebagai berikut: Menghubungi para ahli diantaranya ahli isi pembelajaran, ahli desain pembelajaran, dan ahli asesmen pembelajaran; Memberikan Instrumen penilaian kepada ahli isi pembelajaran, ahli desain pembelajaran, dan ahli asesmen pembelajaran; Analisis hasil penilaian para ahli dan Pelaksanaan uji coba lapangan.

Uji coba produk dalam penelitian pengembangan ini terdiri atas: desain uji coba melalui dua tahap, yaitu uji coba tingkat validitas dan uji coba tingkat efektivitas; subjek uji coba dalam penelitian ini dilakukan oleh satu orang ahli isi bidang studi, satu orang ahli desain pembelajaran dan ahli Asesmen pembelajaran. Ahli isi bidang studi atau mata pelajaran dalam penelitian pengembangan ini adalah seorang guru mata pelajaran IPA di SD Negeri 1 Sangsit. Ahli desain dan Asesmen pembelajaran yang diminta kesediannya untuk mereview rancangan Asesmen Proyek dengan spesifikasi minimal Sarjana (S1) di Universitas Pendididkan Ganesha dan tahap uji lapangan dilakukan oleh siswa; jenis data dalam penelian ini menggunakan data kuantitatif dan kualitatif; metode pengumpulan data; instrumen pengumpulan data, dan teknik analisis data. Penelitian ini menggunakan dua metode pengumpulan data untuk menjawab permasalahan mengenai rancangan desain pengembangan asesmen proyek, kualitas hasil pengembangan asesmen proyek serta efektivitas pengembangan produk yaitu metode kuesioner dan tes.

Adapun penjabaran dari masingmasing metode adalah sebagai berikut. 
Kuesioner digunakan untuk mengumpulkan data hasil review dari ahli isi bidang studi atau mata pembelajaran, ahli desain pembelajaran, ahli asesmen pembelajaran dan uji lapangan. Metode Tes Instrumen yang digunakan untuk mengukur hasil belajar siswa adalah tes objektif. Nitko (dalam Koyan, 2012) memberikan pendapat tentang tes objektif merupakan butir tes pilihan ganda terdiri dari satu atau lebih kalimat pengantar dan diikuti oleh daftar tentang dua atau lebih jawaban. Peserta didik diminta memilih jawaban yang benar pada alternatif jawaban di daftar.

Instrumen tes objektif digunakan pada pengumpulan data uji efektifitas hasil belajar siswa untuk mendapatkan skor hasil belajar pada kegiatan pretest dan posttest baik pembelajaran sebelum dan sesudah menggunakan Asesmen Proyek. Hasil dari metode tes digunakan untuk uji efektifitas produk hasil belajar siswa. Dalam penelitian pengembangan ini digunakan tiga teknik analisis data, yaitu teknik analisis deskriptif kualitatif, teknik analisis deskriptif kuantitatif dan metode analisis statistik Inferensial/induktif.

Analisis deskriptif kualitatif merupakan suatu teknik yang nmenggambarkan dan menginterpretasikan arti data-data yang telah terkumpul dengan memberikan perhatian dan merekam sebanyak mungkin aspek situasi yang diteliti pada saat itu sehingga memperoleh gambaran secara umum dan menyeluruh tentang keadaan sebenarnya.

Dalam Agung (2012) "analisis deskriptif kualitatif yaitu suatu cara analisis atau pengolahan data dengan jalan menyusun secara sistematis dalam bentuk kalimat/kata-kata, kategori-kategori mengenai suatu subjek (benda, gejala, variabel tertentu), sehingga akhirnya diperoleh simpulan umum".

Teknik analisis deskriptif kualitatif ini digunakan untuk mengolah data hasil review ahli isi mata pelajaran, ahli desain pembelajaran, ahli asesmen pembelajaran dan uji coba siswa. Teknik analisis data ini dilakukan dengan mengelompokkan informasi dari data kualitatif yang berupa masukan, tanggapan, kritik dan saran perbaikan yang terdapat pada angket. Hasil analisis ini kemudian digunakan untuk merevisi produk. yang dikembangkan. Analisis deskriptif kuantitatif adalah suatu cara pengolahan data yang dilakukan dengan jalan menyusun secara sistematis dalam bentuk angka-angka atau persentase, mengenai suatu objek yang diteliti, sehingga diperoleh kesimpulan umum" Agung (2012). Dalam penelitian ini, analisis deskriptif kuantitatif digunakan untuk mengolah data yang diperoleh melalui angket dalam bentuk skor.dapat dilihat pada tabel 1 .

Tabel 1. Konversi PAP Tingkat Pencapaian dengan skala 5

\begin{tabular}{ccc}
\hline Tingkat pencapaian & Kualifikasi & Keterangan \\
\hline $90 \%-100 \%$ & Sangat baik & Tidak perlu direvisi \\
$75 \%-89 \%$ & Baik & Sedikit direvisi \\
$65 \%-74 \%$ & Cukup & Direvisi secukupnya \\
$55 \%-64 \%$ & Kurang & Banyak hal yang direvisi \\
$0-54 \%$ & Sangat kurang & Diulangi membuat produk \\
\hline
\end{tabular}

(Tegeh \& Kirna, 2010: 101)

Analisis Statistik inferensial. Analisis ini digunakan untuk mengetahui tingkat efektivitas produk terhadap hasil belajar siswa pada siswa SD Negeri 1 Sangsit sebelum dan sesudah menggunakan produk pengembangan multimedia pembelajaran interaktif. Data uji coba kelompok sasaran dikumpulkan dengan menggunakan pretest dan post test terhadap materi pokok yang diuji cobakan. Hasil pre-test dan post-test kemudian dianalisis menggunakan uji-t untuk mengetahui perbedan antara hasil pretest dan post-test. Sebelum melakukan uji hipotesis (uji-t berkorelasi) dilakukan uji prasyarat (normalitas dan homogenitas). Rumus untuk menghitung uji prasyarat dan uji hipotesis (uji-t berkorelasi) adalah sebagai berikut. Uji normalitas dilakukan untuk mengetahui apakah sebaran skor pada setiap variabel berdistribusi normal atau tidak, untuk itu dapat digunakan rumus Chi-Kuadrat. Kriteria pengujian, data 
berdistribusi normal jika $\chi^{2}$ hitung $<\chi^{2}$ tabel pada taraf signifikansi $\alpha=0,05$ dengan derajat kebebasan k-1.

Uji homogenitas ini dilakukan untuk mencari tingkat kehomogenan secara dua pihak yang diambil dari kelompok-kelompok terpisah dari satu populasi yaitu kelompok kontrol dan kelompok eksperimen. Uji Homogenitas varians untuk kedua kelompok. Kriteria pengujian $\mathrm{H} 0$ diterima jika $F_{\text {hitung }}<\mathrm{F}_{\text {tabel }}$ yang berarti sampel homogen. Uji dilakukan pada taraf signifikan 5\% dengan derajat kebebasan untuk pembilang $\mathrm{n}_{1}-1$ dan derajat kebebasan untuk penyebut $n_{2}-1$.

Uji hipotesis yang dilakukan dalam penelitian ini menggunakan Analisis Uji-t, karena penelitian ini merupakan penelitian dengan membandingkan hasil pretest dan hasil posttes. Hipotesis yang diambil yaitu sebagai berikut.

Pengujian hipotesis penelitian dilakukan dengan analisis uji-t sampel berkorelasi dengan rumus product moment. Semua pengujian hipotesis dilakukan pada taraf signifikansi 5\%. Kriteria pengujian adalah apabila hasil perhitungan diperoleh nilai thitung $>t_{\text {tabel }}$ maka $\mathrm{H}_{0}$ ditolak dan $\mathrm{H}_{1}$ diterima.

\section{HASIL DAN PEMBAHASAN}

Produk yang dihasilkan dalam penelitian ini adalah buku pedoman untuk guru yang berupa instrumen Asesmen proyek. Sebelum memproduksi produk pengembangan perlu dilakukan tahap analisis dan perencanaan. Tahap analisis bertujuan ntuk menentukan kompetensi yang sesuai untuk penilaian proyek, menyusun indikator proses dan hasil belajar berdasarkan kompetensi serta merancang tugas yang akan digunakan dalam penilaian kinerja. Selanjutnya pada tahap perencanaan yang perlu dilakukan yaitu: menyusun kisi-kisi instrument; menyusun skala instrument dan membuat kriteria penilaian atau rubrik.

$$
\text { Kualitas hasil pengembangan }
$$

produk. Dalam hal ini dipaparkan empat hal pokok, yaitu hasil uji ahli isi mata pelajaran, uji ahli desain pembelajaran, uji ahli asesmen pembelajaran, dan uji coba lapangan. keempat data tersebut akan disajikan secara berturut-turut sesuai dengan hasil yang diperoleh dari masingmasing tahapan uji coba.

Uji ahli isi mata pelajaran, produk ini dinilai oleh seorang ahli isi sekaligus sebagai guru mata pelajaran IPA di SD Negeri 1 Sangsit Instrumen yang digunakan untuk uji coba ahli isi mata pelajaran ini adalah angket/kuisioner. Metode yang digunakan untuk mengumpulkan data adalah metode kuisioner. Berdasarkan hasil penilaian dari ahli isi mata pelajaran, setelah dikonversikan dengan tabel konversi, persentase tingkat pencapaiannya sebesar $96 \%$ berada pada kualifikasi sangat baik, sehingga dari segi isi/substansi materi yang disajikan dalam Asesmen proyek ini tidak perlu direvisi.

Uji ahli desain pembelajaran, produk asesmen proyek ini di nilai oleh ahli desain pembelajaran. Berdasarkan hasil penilaian dari ahli desain pembelajaran, Setelah dikonversikan dengan tabel konversi, persentase tingkat pencapaiannya sebesar 92\% berada pada kualifikasi sangat baik, sehingga dari segi desain pembelajaran dalam Asesmen proyek ini tidak perlu direvisi.

Uji ahli asesmen pembelajaran. produk asesmen proyek di nilai oleh seorang ahli asesmen pembelajaran. Berdasarkan hasil penilaian dari ahli asesmen pembelajaran, Setelah dikonversikan dengan tabel konversi, persentase tingkat pencapaiannya sebesar $94 \%$ berada pada kualifikasi sangat baik, sehingga dari segi isi/substansi materi yang disajikan dalam asesmen proyek ini tidak perlu direvisi.

Uji coba lapangan. Sebagai subjek coba dalam uji coba lapangan yaitu kepada kelas $\mathrm{V}$ dengan jumlah siswa sebanyak 29 orang siswa SD Negeri 1 Sangsit. Berdasarkan hasil penilaian diperoleh hasil sebesar $91,7 \%$ berada pada kualifikasi sangat baik, sehingga asesmen yang dikembangkan tidak perlu direvisi. Dalam pengembangan asesmen proyek ini melalui empat tahapan yaitu uji ahli isi mata pelajaran, uji ahli desain pembelajaran, uji ahli asesmen pembelajaran, dan uji coba lapangan. Dalam tahapan ke empat tersebut tidak ada berarti yang perlu direvisi namun hanya ada beberapa tambahan dan masukan dari para ahli dan subjek uji coba. 
Sebelum menguji efektivitas produk pengembangan asesmen proyek dalam mata pelajaran IPA, dilakukan pretest terhadap 29 siswa di kelas V SD Negeri 1 Sangsit. Selanjutnya diteruskan melakukan posttest terhadap 29 siswa. Adapun hasil pretest dan posttest sebagai dalam tabel berikut.

Dari hasil analisis pretest dan posttest 29 siswa didapatkan skor rata-rata pretest sebesar 59,03 dan skor rata-rata posttest sebesar 77,79 . Berdasarkan nilai pretest dan posttest 29 siswa tersebut, maka dilakukan uji-t untuk sampel berkorelasi secara manual. Sebelum melakukan uji hipotesis (uji-t), perlu dilakukan uji prasyarat analisis data yang meliputi uji normalitas dan uji homogenitas. Adapun pemaparannya sebagai berikut: Uji Normalitas, Uji normalitas data dilakukan untuk menyajikan bahwa sampel benar-benar berasal dari populasi yang berdistribusi normal. Uji normalitas data dilakukan terhadap data 29 siswa dari hasil belajar IPA siswa yang terdiri dari dua kelompok yaitu: hasil belajar IPS siswa yang mengikuti pembelajaran tanpa menggunakan Asesmen proyek, dan hasil belajar IPA siswa yang mengikuti pembelajaran dengan menggunakan asesmen proyek. Uji normalitas data dilakukan dengan teknik Chi-Kuadrat. Berdasarkan hasil analisis uji normalitas data yang dilakukan.

Berdasarkan terlihat bahwa hasil perhitungan dengan menggunakan rumus chi-kuadrat, diperoleh $\quad \chi^{2}{ }_{\text {hitung }}<\chi^{2}$ tabel dengan taraf signifikansi $5 \%$. Dengan demikian semua data skor hasil belajar IPA siswa berdistribusi normal; Uji Homogenitas, Homogenitas data dianalisis dengan uji-F, dengan kriteria data homogen jika $\mathrm{F}_{\text {hitung }} \leq \mathrm{F}_{\text {tabel }}$, dan data tidak homogen jika $\mathrm{F}_{\text {hitung }} \geq \mathrm{F}_{\text {tabel }}$.

Dari hasil pengujian diperoleh Fhitung $=1,36$ sedangkan Ftabel= 2,048 dengan taraf signifikansi $5 \%$. Jadi dapat disimpulkan Fhitung $\leq$ Ftabel sehingga kedua data tersebut memiliki varian yang

Homogeny; Uji Hipotesis, Pengujian hipotesis penelitian dilakukan dengan analisis uji-t sampel berkorelasi. Semua pengujian hipotesis dilakukan pada taraf signifikansi 5\%. Kriteria pengujian adalah apabila hasil perhitungan diperoleh nilai thitung > ttabel maka $\mathrm{HO}$ ditolak dan $\mathrm{H} 1$ diterima. Hasil uji-t disajikan pada tabel 2 sebagai berikut

Tabel 2 Rangkuman Hasil Uji-t

\begin{tabular}{ccccccc}
\hline Data & $\mathbf{N}$ & Rata-rata & $\begin{array}{c}\mathbf{s}^{\mathbf{2}} \\
\text { (Varians) }\end{array}$ & $\begin{array}{c}\mathbf{d b} \\
\left(\mathbf{n}_{\mathbf{1}}+\mathbf{n}_{\mathbf{2}} \mathbf{- 2}\right)\end{array}$ & $\mathbf{t}_{\text {hitung }}$ & $\mathbf{t}_{\text {tabel }}$ \\
\hline Pretest & 29 & 59,03 & 47,39 & 56 & 13,693 & 2.000 \\
Posttest & 29 & 77,79 & 29,95 & 56 & & \\
\hline
\end{tabular}

Berdasarkan hasil uji-t diperoleh thitung $=13,693$ dan tabel $=2,000$ untuk $\mathrm{db}=56$ dari taraf signifikansi $5 \%$. Hal ini berarti $t_{\text {hitung }}>$ $t_{\text {tabel}}$, sehingga $\mathrm{H}_{0}$ ditolak dan $\mathrm{H}_{1}$ diterima. Berdasarkan kriteria pengujian, $\mathrm{H}_{0}$ ditolak dan $\mathrm{H}_{1}$ diterima yang artinya terdapat perbedaan hasil belajar siswa sebelum menggunakan asesmen proyek dan sesudah menggunakan asesmen proyek pada siswa kelas V Semester Genap pada pembelajaran IPA tahun ajaran 2015/2016 di SD Negeri 1 Sangsit. Hal ini menunjukkan bahwa asesmen proyek memberikan pengaruh kepada siswa terhadap hasil belajar dalam pembelajaran IPA. Ini dikarenakan proses belajar mengajar dengan menggunakan asesmen proyek dapat memudahkan guru dalam melakukan pembelajaran IPA dan siswa akan mudah mengingat materi ajar. Dengan demikian asesmen proyek memiliki kontribusi dalam peningkatan hasil belajar siswa.

Hal ini mendukung teori yang diungkapkan Rasyid (2007) bahwa penilaian (asesmen) adalah untuk mengetahui tingkat ketercapaian tujuan pembelajaran dan melihat keefektifan proses belajar mengajar, selanjutnya pendapat yang hampir sama dikemukakan oleh Kellough (2007) mengidentifikasi penilaian adalah untuk: 
membantu belajar siswa; mengidentifikasi kekuatan dan kelemahan; menilai efektivitas strategi pengajaran; menilai dan meningkatkan efektivitas program kurikulum, dan menilai dan meningkatkan efektivitas pengajaran.

Hasil penelitian ini mendukung penelitian yang dilakukan oleh Widiana dkk. (2016) yang berjudul statistik inferensial dari kelompok siswa yang mengikuti model pembelajar) yang memperoleh hasil bahwa: dalam model pembelajaran SCSS, siswa berprestasi statistik inferensial yang mendapat penilaian kinerja lebih tinggi dari kelompok yang mendapat penilaian konvensional; dalam model pembelajaran konvensional, siswa berprestasi statistik inferensial yang mendapat penilaian kinerja yang lebih rendah dibandingkan kelompok yang mendapat penilaian konvensional; dalam penilaian kinerja, siswa berprestasi statistik inferensial yang mengikuti studi dengan SCSS model pembelajaran lebih tinggi dari pada mereka yang mengikuti model pembelajaran konvensional dan dalam penilaian konvensional, prestasi statistik inferensial siswa yang mengikuti model pembelajaran SCSS lebih rendah dari kelompok yang mengikuti model pembelajaran konvensional.

Selanjutnya penelitian ini juga sejalan dengan penelitian yang dilakukan oleh Megawati et al Mahasiswa Universitas Pendidikan Ganesha (2012) dalam jurnal yang berjudul Penerapan Pendekatan Saintifik dengan Penilaian Proyek untuk Meningkatkan Kemampuan Penalaran dan Hasil Belajar Pengetahuan Matematika Siswa Kelas IVB SD dapat disimpulkan bahwa setelah pembelajaran matematika dengan penerapan pendekatan saintifik dapat meningkatkan kemampuan penalaran pengetahuan matematika siswa dengan rata-rata nilai kemampuan siswa pada siklus pertama $68,88 \%$ dan pada sikluas II menjadi $82,73 \%$. Penelitian yang dilakukan Meliawati (2012) dalam penelitiannya yang berjudul Penggunaan Penilaian Proyek dalam Upaya Meningkatkan Hasil Belajar Siswa pada Konsep Ekosiskem di Kelas VII yang menghasilkan kesimpulan bahwa penilaian proyek dapat meningkatkan hasil belajar siswa. Hasil penelitian menunjukkan bahwa pembelajaran menggunakan penilaian proyek lebih baik digunakan dari pada model pembelajaran konvensional. Hal ini terlihat pada penelitian yang telah dilaksnakan. Pembelajaran berbasis proyek memberikan kesempatan kepada siswa untuk belajar menumbuh kembangkan aspek-aspek minat belajar dan kesempatan menyelesaikan permasalahan yang konkrit yang membuat pembelajaran lebih bermakna.

\section{SIMPULAN DAN SARAN}

Berdasarkan rumusan masalah, hasil analisis data dan pembahasan pada penelitian ini, maka dapat diambil simpulan sebagai berikut pertama desain pengembangan asesmen proyek diawali melalui analisis kebutuhan dan permasalahan pembelajaran yang di SD Negeri 1 Sangsit. Perancangan desain Asesmen Proyek dilakukan dengan membuat, pertama, Kisi-kisi instrument penilaian kedua, Skala instrument penilaian, ketiga, Rubrik penilaian. Kemudian mengajak siswa belajar dalam kelompok dan membuat suatu proyek yang nantinya akan dinilai oleh guru. Sebelum pembuatan proyek siswa ditugaskan untuk menyiapkan alat dan bahan yang diperlukan dalam pembuatan proyek. Selanjutnya siswa ditugaskan untuk membuat laporan hasil pembuatan proyek yang mereka buat dan membacakannya di depan kelas. Kedua kualitas hasil pengembangan asesmen proyek dalam pembelajaran IPA yang dilakukan oleh satu, ahli isi mata pelajaran berada pada kategori sangat baik, dengan persentase 96\%; dua, ahli desain pembelajaran berada pada kategori sangat baik, dengan persentase 92\%; tiga,ahli asesmen pembelajaran pada kategori sangat baik dengan persentase 94\% dan keempat, uji coba lapangan berada pada kategori sangat baik dengan persentase 90,5\%. Ketiga Efektivitas produk Asesmen Proyek dalam pembelajaran IPA terdapat belajar siswa yang signifikan setelah mengikuti pembelajaran menggunakan asesmen proyek pada siswa kelas $\mathrm{V}$ Semester Genap Tahun Pelajaran 2015/2016 di SD Negeri 1 Sangsit. Perbandingan hasil perhitungan rata-rata sesudah menggunakan Asesmen Proyek adalah 77,79 lebih besar dari rata-rata 
sebelum menggunakan Asesmen Proyek 59,03 dengan thitung $=13,693>t_{\text {tabel }}=2,000$ pada taraf signifikansi $5 \%$.Saran-saran yang disampaikan bekenaan dengan pengembangan Asesmen Proyek dalam pembelajaran IPA dikelompokkan menjadi empat bagian diantaranya satu, kepada guru; dua, kepada kepala sekolah, dan kepada peneliti lain. Satu, Kepada Sekolah, Asesmen Proyek ini dapat dikembangkan di Sekolah dalam memberikan penilaian yang sesuai dengan kemampuan siswa setiap proses pembelajaran yang ada di sekolah. Sekolah dapat menggunkan Asesmen Proyek sebagai alternative untuk mengevaluasi hasil akhir suatu pembelajaran. Dua, Kepada Guru. Guru disarankan agar lebih intens menggunakan Asesmen Proyek dalam pembelajaran IPA, mengingat fasilitas lingkungan sekolah dan siswa sangat mendukung dalam penyampaian dan penyerapan materi dalam pembelajaran IPA kepada siswa. Ketiga, Kepada peneliti lain. Berdasrkan penelitian yang sudah dilakukan diharapkan dapat menarik minat peneliti yang lain untuk mengembangkan lagi penelitian Pengembangan Asesmen Proyek ini yang nantinya akan lebih diteliti secara lebih mendalam dalam pembelajaran yang berbeda.

\section{DAFTAR PUSTAKA}

Agung, Anak Agung Gede. 2012. Metodelogi Penelitian Pendidikan. Singaraja: UNDIKSHA.

Depdiknas. (2006). Standar Isi dan Standar Kompetensi Lulusan Permendiknas No. 24 Tahun 2006.

Hasbullah. 2009. Dasar-Dasar IImu Pendidikan. Jakarta: Penerbit Bumi Pers

Khusniati, M. (2012). Pendidikan Karakter Melalui Pembelajaran Ipa. Jurnal Pendidikan IPA Indonesia, 1(2), 204210. Retrieved from http://journal.unnes.ac.id/nju/index.p hp/jpii/article/view/2140

Koyan, I Wayan. 2012. Stastistik Pendidikan Teknik Analisis Data Kuantitatif: Universitas Pendidikan Ganesha Press
Listyawati , Ni Nym, M. S. D. N. S. (2013, July 3). Pengaruh Model Pembelajaran Kuantum Berbantuan Peta Pikiran Terhadap Kemampuan Berpikir Kritis Siswa Pada Pembelajaran Ipa Kelas V Sd. Mimbar PGSD. Retrieved from http://ejournal.undiksha.ac.id/index.p hp/JJPGSD/article/view/779

Listyawati, M. (2012). Pengembangan Perangkat Pembelajaran Ipa Terpadu Di Smp. Journal of Innovative Science Education, 1(1), 61-69.

M. Jaya Adi Putra, S. S. M. P. (2015, September 9). Pengaruh Peer Coaching Terhadap Praktek Pembelajaran Ipa Guru Sd (Studi Kuasi Eksperimen Sd Di Pekanbaru). Jurnal Primary. Retrieved From Http://Ejournal.Unri.Ac.Id/Index.Php/ Jpfkip/Article/View/2817

Marhaeni, AAIN. 2007. Pembelajaran Inovatif dan Assessment Otentik dalam Rangka Menciptakan Pembelajaran yang Efektif dan Produktif.

http://www.undiksha.ac.id/elearning/ staff/images/img_info/4/2-282.pdf. Download 05-01-2011

Megawati, T. A., Wiarta, I W., \& Manuaba S. (2015) Penerapan Pendekatan Saintifik dengan Penilaian Proyek untuk Meningkatkan Kemampuan Penalaran dan Hasil Belajar Pengetahuan Matematika Siswa Kelas VIB SD. e-Journal PGSD Universitas Pendidikan Ganesha. 3(1). 1-10. Tersedia pada ejurnal.undiksha.ac.id. Diaskses 28 Desember 2015

Morrison, JA, dan Estes, JC. 2007. Using Scientist and Real-World Scenario in Professional Development for Middle School Science Teacher. Journal of Science Teacher Education. 18 (2): 165-184.

Muslich, Masnur. 2009. KTSP Pembelajaran Berbasis Kompetensi dan Kontekstual. Jakarta: Bumi Aksara 
National Research Council. (1996). National Science Education Standard. Washington, DC: National Academy Press. http :// books .nap.edu/html /inquiryaddendum/ notice.html.

Purnamasari, J., Herpratiwi, H., \& Kandar, S. (2015, January 9). Evaluasi Pembelajaran Ipa Berbasis Pendidikan Karakter. Jurnal Teknologi Informasi Komunikasi Pendidikan. Retrieved from http://jurnal.fkip.unila.ac.id/index.php /JTP/article/view/1551

Puspitorini, R., Prodjosantoso, A. K., Subali, B., \& Jumadi, J. (2014, October 9). Penggunaan Media Komik Dalam Pembelajaran Ipa Untuk Meningkatkan Motivasi Dan Hasil Belajar Kognitif Dan Afektif. Cakrawala Pendidikan. Retrieved from

http://journal.uny.ac.id/index.php/cp/ article/view/2385

Rasyid, Harun dan Mansur. 2007. Penilaian Hasil Belajar. Bandung: CV. Wacana Prima.

Rizal. (2014). Pengaruh pembelajaran inkuiri terbimbing dengan mind map terhadap keterampilan proses sains dan hasil belajar IPA. Jurnal Pendidikan Sains, 2(4), 159-165. Retrieved from http://journal.um.ac.id/index.php/jps

Rusnadi, D. P. P. N. W. A. (2013, July 5). Penerapan Model Pembelajaran Kooperatif Tipe Team Games Tournament Untuk Meningkatkan Kemampuan Berpikir Kritis Dan Hasil Belajar Ipa. MIMBAR PGSD. Retrieved from http://ejournal.undiksha.ac.id/index.p $\mathrm{hp} / J J P G S D / a r t i c l e / v i e w / 881$

Susiani, K., Dantes, N., \& Tika, N. (2013, May 10). Pengaruh Model Pembelajaran Quantum Terhadap Kecerdasan Sosio-Emosional Dan Prestasi Belajar Ipa Siswa Kelas V Sd Di Banyuning. Jurnal Pendidikan Dasar. Retrieved from http://119.252.161.254/e-

journal/index.php/jurnal_pendas/artic le/view/525

Tegeh, I Made dan I Made Kirna. 2010. Metode Penelitian Pengembangan Pendidikan. Singaraja: Universitas Pendidikan Ganesha.

Trisnani, I., Hasyim, A., \& Djasmi, S. (2015, January 12). Evaluasi Program Pembelajaran Ipa. Jurnal Teknologi Informasi Komunikasi Pendidikan. Retrieved from http://jurnal.fkip.unila.ac.id/index.php /JTP/article/view/4778

Uno. 2012. Assessment Pembelajaran. Jakarta: Bumi Aksara.

Wahyuni dan Ibrahim. 2012. Asesmen Pembelajaran Bahasa. Bandung: Refika Aditama

Widiana I Wayan dan Jampel I Nyoman. 2016. Learning Model and Form of Assesment toward the Inferensial Statistical Achievement By Controlling Numeric Thingking Skills. 